\title{
鴊氙 \\ DĀR AL-HARB DAN DĀR AL-ISLĀM: \\ DWIPOLAR POLITIK ISLAM
}

\author{
M. Sidi Ritaudin \\ IAIN Raden Intan Lampung \\ penahoo_sidi@yahoo.co.id
}

\begin{abstract}
Abstrak
Artikel ini mengulas masalah Dār al-harb vis a vis Dar al-Islām, suatu isu yang biasanya melekat dalam setiap gerakan terorisme. Pada tingkat aksi, sekelompok pemikir Islam yang menganut Paradigma Dwipolar menjadikan doktrin tersebut sebagai dasar dalam menggalang semangat jihad (perang suci) ke tengah-tengah masyarakat Muslim. Dalam pandangan mereka, konsep Dār Al-Harb dan Dār Al-Islām merupakan doktrin politik Islam yang amat penting sekaligus menjadi jiwa bagi setiap kegiatan jihad. Masalahnya sekarang adalah apakah konsep tersebut masih relevan dengan kondisi peta politik masa kini di mana interaksi umat manusia di gelanggang Internasional telah sedemikian intens dan manusia secara berangsur-angsur terlebur menjadi masyarakat yang plural.
\end{abstract}

\begin{abstract}
This article covers the issue of Dār al-harb vis a vis the Dar al-Islam, an issue that is usually inherent in any terrorist acts. At the level of action, a group of Islamic thinkers who embrace this bipolar paradigm makes the doctrine as a basis for raising the spirit of jihad (holy war) among the Muslim community. In their view, the concept of Där Al-Harb and the Dar al-Islam is an important political doctrine as well as the soul of every jihad activities. The issue now, however, is whether the concept still relevant to the current political map where the interaction of the human race in the International arena has been so intense and the people are gradually disolved into pluralistic society.
\end{abstract}

Kata Kunci : Pluralisme, Dwipolar, dār al-harb, dār al-Islām, geopolitik. 


\section{A. Pendahuluan}

Pemetaan geopolitik dār al-harb vis a vis dār al-Islām dalam konteks pemikiran kontemporer nampaknya perlu ditinjau ulang. Paling tidak, alasan mendasar adalah tidakditemukannya nash al-Qur'ān maupun Sunnah yang membicarakan kedua konsep tersebut. Oleh karena itu pula, konsep ini ditengarai tidak memiliki hubungan dengan sumber pokok Islam, yang prinsip-prinsipnya ditujukan untuk seluruh alam (lil-'álamìn), sepanjang waktu dan melampaui batasan geografis.

Islam tumbuh dan berkembang, baik melalui dakwah maupun pertumbuhan penduduk yang menyebar melaui proses migrasi, perdagangan, pendidikan dan lain sebagainya (disebut juga sebagai mobilitas penduduk). Mobilitas penduduk yaitu perpindahan penduduk dari satu daerah ke daerah lain. Mobilitas dibedakan atas dua, yaitu mobilitas nonpermanen (tidak tetap) dan mobilitas permanen (tetap). Apabila perpindahan bertujuan untuk menetap di daerah tujuan maka disebut migrasi, umpamanya urbanisasi, imigrasi, emigrasi dan remigrasi. ${ }^{1}$

Mobilitas penduduk ini merupakan relaitas kehidupan manusia dalam bermasyarakat, berbangsa dan bernegara. Jutaan orang Muslim hidup di Eropa, mayoritasnya mendapatkan kebebasan beribadah, mengorganisasi diri, dan bertindak dalam batas-batas beragam konstitusi yang juga melindungi hak-hak mereka. Dalam konteks ini, apakah konsep-konsep lama tentang dwipolar dār al-harb vis a vis dār al-Islām masih relevan dengan situasi tersebut? Apakah antitesis, fenomena dua spektrum, sebutan dār alharb dan dār al-Islām masih sesuai dengan kondisi dunia yang sudah semakin sempit; terbukanya era globalisasi dengan kemunculan teknologi komunikasi dan informasi seperti sekarang ini di mana konfigurasi geopolitik yang sangat kompleks dan daerah kekuasaan serta pengaruh dengan multi dimensi ?

Realitas politik internasional tidak menampakkan posisi menguntungkan bagi kehidupan Muslim² dengan prinsip rahmatan

${ }^{1}$ Lihat, Sri Hayati dan Ahmad Yani, Geografi Politik, (Bandung: Refika Aditama, 2007), h. 86.

${ }^{2}$ Ada sementara pengamat mengatakan bahwa agama dapat menyesuaikan diri dengan problema kemodernan. Bahkan ada yang telah membuktikan bahwa hukum internasional, pada dasarnya, tidak asing dari Islam. Lihat, Mohammad 
lil-āalamin jika masih mempertahankan prinsip paradigma lama tersebut. Sebab persoalan mendasar adalah apakah Muslim di Eropa (Barat, termasuk Australia) harus menganggap dirinya berada di tanah asing, sebagai orang-orang asing, yang berkewajiban hanya melindungi diri mereka di lingkungan yang agresif, atau sebaliknya, apakah mereka harus menjadi bagian dari negara ini, menganggap negara sendiri, sebagai warga negara sejati yang, dalam lingkup hukum, harus bertindak sebaik mungkin dengan memperlakukan masyarakatnya secara lebih adil dan bertenggang rasa, menetapkan nilai-nilai yang bersesuaian dengan nilai yang dituntut oleh agama, hati nurani dan kewarganegaraan mereka. ${ }^{3}$

\section{B. Paradoksalitas Paradigma}

Terminologi dār al-Istām diterjemahkan, tentu saja, tidak berdasarkan pengertian etimologi, karena kata dār, jika diterjemahkan secara harfiah berarti rumah, tempat atau daerah. Istilah-istilah tersebut walaupun sesuai dengan terjemahan harfiah dàr, tetapi tidak memberikan arti politik yang tepat. Oleh karena itu dār al-Islām diartikan sebagai wilayah atau kawasan Islam. Terhadap kawasan/ wilayah Islam ini terdapat kawasan/wilayah perang, yang diterjemahkan dari dār al-harb. Pembagian geopolitik ini ke dalam dua wilayah seperti di atas, menurut Boisard merupakan doktrin klasik. ${ }^{4}$ Sebagai doktrin klasik dapat ditegaskan dengan pernyataan Nurcholish Madjid berikut ini: "Puncak dari 'sumerisme' itu, dalam artinya sebagai peradaban duniawi dalam bentuk masyarakat berkota (citied society) dengan daerah ekonomi agraris dengan pengembangan serta peningkatan optimal aspek kemanusiaannya ialah dār alIslām yang berhasil mendominasi ummat manusia selama paling sedikitnya delapan abad". Sementara Anthoni Black mengungkap tiga abad Islam pertama. ${ }^{5}$ Tentu saja yang dimaksud adalah abad

T. Ghunaimi, The Muslim Conception of International Law and the Western Approach, (La Haye: Nijhoff, 1968), XV, h. 228.

${ }^{3}$ Pemaparan secara komprehensif dapat dibaca pada, Tariq Ramadan, Teologi Dialog Islam-Barat Pergumulan Muslim Eropa, (Bandung: Penerbit Mizan, 2002), h. 139.

${ }^{4}$ Marcel A. Boisard, Humanisme dalam Islam, (terjemahan M. Rasjidi), (Jakarta: Bulan Bintang, 1980), h. 232.

${ }^{5}$ Lihat, Nurcholish Madjid, (ed.), Khazanah Intelektual Islam, (Jakarta: Bulan 
kejayaan Islam yang dimulai dari perkembangan Islam awal masa Nabi dan Khulafā al-Rāsyidīn.

Dār al-Islām, menurut pengertian yang diberikan oleh Hodgson adalah negeri-negeri di bawah kekuasaan Muslim; kemudian negeri mana saja di mana lembaga-lembaga Muslim dipertahankan, apakah di bawah kekuasaan Muslim atau tidak. Istilah ini merupakan kebalikan dari Dār al-harb, yaitu negeri-negri di bawah kekuasaan non-Muslim. ${ }^{6}$ Pengertian ini agaknya tidak cukup untuk penjelasan terhadap perkembangan modern dunia Islam, terutama dari perspektif geopolitik.

Dār al-Islām (wilayah Islam), disebut juga dār al-‘adl (wilayah keadilan), atau dār al-Tauhìd (wilayah orang yang beriman kepada Ke-Esaan Tuhan). Wilayah Islam tentu wilayah kaum Muslimin, tempat sistem pemerintahan Islam diberlakukan (meskipun kaum non-Muslim menjajahnya. Dalam pengertian ini terlihat perbedaan antara orang Muslim yang keberadaan dan jumlahnya benar-benar mengungkapkan ide tentang "kepemilikan wilayah" (al-milkiyyat li al-muslimīn) dan para pemimpin yang bisa saja non-Muslim. ${ }^{7}$ Ulama mazhab Hanafi memberi tekanan pada situasi kaum Muslim yang sangat spesifik : keamanan mereka. Jadi, menurut mereka, bukti bahwa kaum Muslim berada dalam dār al-Islām adalah ketika kaum Muslim aman dan merasa tidak takut karena agama mereka. Bagi mazhab ini, murni soal keamanan dan perlindungan, bukan soal Islam dan kufur.

Dār al-harb, (wilayah perang), disebut juga dār al-syirk (wilayah politeisme) lawan dari dār al-tauhìd. Pada umumnya ulama bersepakat bahwa suatu negara menjadi dār al-harb jika sistem pemerintahan dan pemerintahannya tidak Islami. Akan tetapi, sebutan ini bukan bergantung pada jenis penduduknya (yang mayoritas bisa saja Muslim), melainkan hukum dan sistem politiknya. Menurut mazhab Hanafi, berbeda dengan dār al-Islām.

Bintang, 1985), h. 52. Anthoni Black, Pemikiran Politik Islam Dari Masa Nabi Hingga Masa Kini, (Jakarta: Serambi, 2006), h. 55 dan 107.

${ }^{6}$ Marshall G. S. Hodgson, The Venture of Islam (Iman dan Sejarah dalam Peradaban Dunia Masa Klasik Islam) Buku Kedua, terjemahan Mulyadhi Kartanegara, (Jakarta: Paramadina, 2002), h. 362.

${ }^{7}$ Lihat, Syaikh Mannā' al-Qaththān, Iqāmah al-Muslīm fì Balad Ghair Istāmō (Perkampungan Muslim di Negara Non-Muslim), (Paris : 1993). 
dār al-harb adalah negara tempat kaum Muslimin tidak dilindungi, tidak aman, tidak damai. Eksistensi dār al-harb tidak bergantung pada keadaan perang antara dua faksi yang saling berlawanan. ${ }^{8}$

Tariq Ramadan merespon pendapat di atas dengan mengatakan bahwa mayoritas ulama bersikeras pada kepemilikan wilayah dan aplikasi sistem legal Islam sebagai indeks untuk menetapkan eksistensidāral-Islām. Sedangkanuntukmenetapkan dār al-harb indeks model pemerintahan dan sistem legal dianggap lebih relevan. Tekanan diberikan kepada penduduk menurut pendapat yang pertama, sementara pendapat yang kedua lebih menekankan pada pemerintahan. Abū al-Zarqā dan Yusufal-Qardāwỉ berpendapat bahwa negara-negara Islam yang di dalamnya masih terjadi penindasan, ketidakadilan, dan kediktatoran merajalela masih bisa dianggap sebagai dār al-Islām alasan masih memungkinkan terjadinya reformasi. Berseberangan dengan pendapat ini, adalah parameter yang didasarkan pada keselamatan dan keamanan. ${ }^{9}$ Kaum Muslim terkadang lebih aman di Barat - berkenaan dengan kebebasan mengamalkan agamanya - daripada di negara-negara Islam. Jadi, penyebutan dār al-Islām dapat diaplikasikan pada semua negara Barat, sedangkan mayoritas negara Islam, yang mayoritas penduduknya Muslim, tidak bisa dikatakan demikian. Namun, sebagai catatan harus berhati-hati dengan kesimpulan ini, sebab kecuali parameter keamanan, negara-negara Barat tidak Islami. ${ }^{10}$

\section{Dwipolar Geopolitik Islam}

Pembagian atas dua bagian (kelompok orang yang berkepentingan) yang berlawanan (dwipolar), yatu dār al-harb dan dār al-Islām, tentu saja masih dipertanyakan keabsahannya. Sebelumnya, mungkin ada relevansinya dikemukakan terlebih dahulu di sini

${ }^{8}$ Lihat, Marcel A. Boisard, Humanisme dalam Islam, ( terjemahan H.M. Rasjidi), (Jakarta: Bulan Bintang, 1980), h. 233.

${ }^{9}$ Paradoksalitas antara paradigma dār al-Islām dengan dār al-harb liahat juga, Nurcholish Madjid, (ed.), Khazanah Intelektual Islam, (Jakarta: Bulan Bintang, 1985), h. 13. Dār al-Islām dalam konteks kemodernan menurut Nurcholish Madjid dapat dipandang sebagai kelanjutan langsungnya masyarakat berkota (citied society), terutama jika dilihat dari segi pola kehidupan sosial-ekonominya. Lihat, Ibid., h. 54.

${ }^{10}$ Tariq Ramadan, Teologi Dialog Islam-Barat Pergumulan Muslim Eropa, (Bandung : Penerbit Mizan, 2002), h. 143-144.. 
pendapat Frithjof Schuon bahwa "Islam menyebar ke seluruh dunia bagaikan kilat berkat substansinya, dan penyebarannya terhenti dikarenakan bentuknya". ${ }^{11}$ Dua terminologi yang harus digaris bawahi dari pernyataan Schuon ini, yaitu substansi dan bentuk. Dalam konteks dār al-Islām, dapat dikonotasikan pada substani, sedangkan dār al-harb adalah bentuk. Ketika Islam diberi bentuk yang nisbi, seperti isme-isme yang merupakan buah pikiran manusia, maka terjadilah debatabel bahkan perseteruan yang pada ujungnya menyebabkan kejatuhan dan keterpurukan. Namun demikan istilah ini dipergunakan untuk memudahkan dalam melihat Islam dalam potret geopolitik. ${ }^{12}$ Dār al-harb dan dār al-Islām merupakan batas wilayah yang tidak didasarkan pada batas-batas wilayah sebagaimana batas-batas negara, tetapi batasanya adalah wilayah ideologis, yaitu ideologi Islam dan non Islam.

Islam, baik dalam Wahyu maupun Sunnah, tidak mengenalkan kedua istilah tersebut, namun demikian, secara stereotip kalangan Muslim tidak memandangnya sebagai suatu hal yang asing dalam istilah pemikiran politik Islam. Karena tidak memiliki dasar normatif yang valid, dan ditengarai adanya istilah dār al-harb yang dihadapkan dengan dār al-Islām telah menyulut semangat jihad dan berkembangnya aliran kekerasan dan teror dalam Islam, tentu saja hal ini patut dicurigai dan perlu dikaji ulang, sebab merugikan Islam dan kalangan Muslim itu sendiri.

Jihad adalah istilah teknis dalam dunia Muslim berasal dari bahasa Arab dan memiliki sejarah perjuangan panjang, dan umumnya berkaitan dengan kawasan-kawasan Muslim Afrika dan Asia yang lebih tua. Banyak kalangan menilai bahwa kata jihad mengandung arti kekerasan. Kata ini paling sering diterjemahkan oleh kaum orinetalis dengan "perang suci”, yaitu perang yang dilancarkan terhadap non-Muslim, semacam kebalikan dari Perang Salib. Sejauh ini, transformasi jihad menjadi ideologi modern berjalan tidak mulus, karena perhatian yang berkurang

${ }^{11}$ Frithjof Schuon, Islam dan Filsafat Perenial, (Bandung: Mizan, 1993), h. 25.

${ }^{12}$ Geopolitik salah satu cabang ilmu pengetahuan yang membahas tentang pengaruh faktor geografi terhadap ketatanegaraan; atau kebijaksanaan negara atau bangsa sesuai dengan posisi geografisnya. Lihat, Departemen Pendidikan dan Kebudayaan, Kamus Besar bahasa Indonesia edisi kedua, (Jakarta : Balai Pustaka, 1995), h. 311. 
pada jihad di beberapa kalangan. Sementara jihad secara retorik mungkin masih memiliki daya tarik di Afrika Utara, Timur Tengah atau bahkan dalam kaitan Asia Selatan, sebaliknya bagi warga Asia Tenggara, dan khususnya bagi kaum Muslim Melayu, jihad (yang dipahami sebagai imbauan untuk melakukan perjuangan bersenjata) sudah dilampaui oleh kebutuhan meletakkan Islam dalam konteks ekonomi Internasional. Jihad telah memperoleh makna perjuangan keadilan sosial dalam lingkungan yang semakin luas, yang juga mencakup partisipasi ekonomi serta kemakmuran bagi kaum Muslim.

Argumentasi di atas diajukan dan merupakan dasar perjuangan kaum Muslim menegakkan syari'ah Islam dalam negara. Semua golongan pemikir garis keras berpandangan demikian, seperti Sayyid Quthb, Abul A’la Maududi, serta kelompok-kelompok pergerakan Islam, seprti Hizbut Tahrir, Ikhwan al-Muslimin, Lasykar Jihad, Jama'ah Islam, Majelis Mujahidin Indonesia dan lain sebagainya.

\section{Antagonisme dwipolar}

Dua entitas dār al-harb dan dār al-Islām memiliki signifikansi pada masa-masa tiga abad Islam pertama ${ }^{13}$ yang dimunculkan dalam wacana pemikiran Islam klasik oleh para ulama, agar orang Muslim memiliki gambaran yang jelas tentang realitas geopolitik pada zaman mereka. Terminologi polarisasi, dalam arti, pembagian atas dua bagian (kelompok orang yang berkepentingan) yang berlawanan (dwipolar dār al-harb dan dār al-Islām). Gagasan ini muncul di abad modern diusung oleh kelompok pemikir Islam fondamentalis skripturalis seperti Sayyid Quthb.

Pemikiran sentral Sayyid Quthb adalah adanya jurang dualisme Manichean ${ }^{14}$ : di satu sisi ada keadilan, aturan

${ }^{13}$ Antony Black menyebut istilah dār al-Islām, pada pembahasan Masa Abbasiyah dan kebangkitan kembali Persia, hal ini menunjukkan bahwa terminologi ini timbul dan berkembang pada masa kejayaan Islam, lihat Anthoni Black, Pemikiran Politik Islam Dari Masa Nabi Hingga Masa Kini, (Jakarta : Serambi, 2006), h. 55 dan 107.

${ }^{14}$ Manicheanisme, adalah sebuah sekte dari jenis gostik yang didirikan pada abd ke-3 di bawah kekuasaan orang-orang Sasani. Orang-orang sasani ini menganut agama Mani. Lihat, Marshall G. S. Hodgson, The Venture of Islam (Iman dan Sejarah 
sesuai dengan perintah al-Qur'an dan Islam, yang merupakan implementasi konsep hakimiyyah, kekuasaan Ilahi. Di sisi lain ada jahiliyyah atau yang menentang hakimiyyah, berlanjutnya kebodohan, pemutarbalikan, serta kekhilafan yang disengaja. Termasuk dalam jahiliyyah adalah penggunaan semua "isme", apakah itu komunisme, kapitalisme, saintisme atau humanisme, selain Tuhan. Nasionalisme pun dengan demikian menjadi salah satu nir-Tuhan-isme (Godlessness). ${ }^{15}$

Sayyid Quthb dengan lantang mengingatkan bahwa kesetiaan pada nasionalisme, seperti halnya pada isme mana pun, adalah salah. Hal ini merupakan fenomena jahiliyyah bagi Quthb. Mengikuti semangat Islam sejati, bila hakimiyyah berlaku, menurut Quthb, “nasionalisme akan diakui sebagai kepercayaan, Tanah Air sebagai dār al-Islām, penguasanya adalah Tuhan, dan konstitusinya adalah al-Qur'an. ${ }^{16}$ Kekuatan Quthb yang menganjurkan Islam sebagai politik keagamaan mereduksi Islam menjadi program protes satu-satunya melawan kekuatan-kekuatan dominan sistem dunia modern. Begitu pun para pengikut pemikiran Quthb dan sejenisnya di Indonesia, protes-protes yang dilancarkan dengan cara kekerasan seperti yang dilakukan oleh Hizbut Tahrir Indonesia umpamanya, jelas sekali mereduksi Islam itu sendiri. Karena kekuatan dominan NKRI adalah kontrak politik yang harus dijalankan oleh seluruh rakyat Indonesia yang telah disepakati oleh siapa pun yang tinggal di dalamnya.

Masyarakat Islam yang hidup dalam komunitas dār al-Islām, menetapkan syari'ah sebagai otoritas sentral, dan prinsip-prinsip Islam harus diterapkan pada semua aspek kehidupan sosial dan ekonomi. Hasilnya adalah masyarakat Islam yang bukan sosialis maupun kapitalis. Masyarakat Islam ideal ini harus dicapai dengan jihad atau perang suci. Cara ini akan menghancurkan semua

dalam Peradaban Dunia Masa Klasik Islam), terjemahan Mulyadhi Kartanegara, (Jakarta: Paramadina, 2002), h. 74.

${ }^{15}$ Penjelasan Lawrence ini dikutip dari buku Sayyid Quthb, "Ma'alim fi alThariq” (Cairo : Dar ash-Shuruq, 1964), lihat, Bruce B. Lawrence, Islam Tidak Tunggal Melepaskan Islam dari Kekerasan, Jakarta : Serambi, 2004) h. 42. Sayyid Quthb, Ma'alim fith-Thariq, (Kairo : Rar Ash-Shuruq, 1964), h. 26.

${ }^{16}$ Sayyid Quthb, Milestones, (Cedar Rapids, Iwoa: Unity Publishing, t.th), h. 126 . 
kekuatan musuh-musuh Islam, yaitu kekuatan jahiliyyah ( yang berada pada posisi dār al-harb). ${ }^{17}$

\section{E. Dampak Pemikiran Dwipolar}

Pengaruh kuat dari paradigma dwipolar dengan terminologi dār al-harb dan dār al-Islām, mendatangkan akibat yang sangat dahsyat, baik segi positif maupun segi negatifnya. Di kalangan umat Islam di mana saja terdapat perasaan tidak senang tertentu terhadap non Muslim, oleh berbagai alasan dan latar belakang. Namun di Barat dikenal sebagai "anti Semitisme" yang sempat memuncak menjadi Genocide dan Holocaust oleh Nazi Jerman, perasaan kurang positif Muslim terhadap non Muslim tidak ada artinya. Bahkan masih dalam batas-batas yang wajar dan manusiawi, seperti halnya setiap perasaan yang ada pada suatu kelompok terhadap kelompok lain. Prasangka dan stereotip negatif adalah bagian dari kenyataan hubungan antar kelompok. Namun tidak semua kelompok membenarkan adanya prasangka dan stereotip kepada kelompok lainnya, dan banyak dari mereka yang berkomitmen untuk memberantasnya. ${ }^{18}$

Kaum Muslim, dalam hubungannya dengan agamaagama lain, khususnya Yahudi dan Kristen, data dikategorikan sebagai kelompok yang berkomitmen untuk memberantas stereotip negatif. Hal ini disandarkan pada sikap Nabi Saw setelah Perjanjian Hudaibiyyah (Sulh al-Hudaibiyyah), yang pada prinsipnya saling berkomitmen dalam perbedaan, saling menghargai dan menghormati satu sama lainnya. Namun demikian, dalam perjalanan sejarah terdapat kasus-kasus yang dapat diungkap, emngapa para ulama klasik mendukung konsep dwipolar tersebut. Di samping adanya gangguan kesejarahan seperti imprialisme Barat dan Zionisme Yahudi pada zaman modern atau pra modern; ada dua kasus yang terjadi pada saat Nabi Saw mengirim dilegasi ke masyarakat di negara-negara tetangga yang sama sekali tidak mengenal Islam, atau yang pemimpinnya tidak mengetahui realitas

${ }^{17}$ Lihat analisis Ian Adams, Ideologi Politik Mutakhir Konsep, Ragam, Kritik, dan Masa depannya, (Yogyakarta : Penerbit Qalam, 2004), h. 434.

${ }^{18}$ Nurcholish Madjid, Islam Doktrin dan Peradaban Sebuah Telaah Kritis tentang Masalah Keimanan, Kemanusiaan, dan Kemodernan, (Jakarta : Paramadina, 2000), h. xc. 
kemunculan agama baru dan yang mendasarkan hukumnya pada perundang-undangan yang tidak adil.

Kasus pertama adalah ketika Nabi Saw mengutus Harits ibn Umair ke Romawi, ia dibunuh oleh Amr al-Ghassani, salah satu dari menteri kekaisaran Romawi, sehingga menyebabkan terjadinya peperangan, yang jelas bukan tujuan dari deligasi tersebut maupun kaidah untuk hubungan dengan bangsa-bangsa tetangga. Kasus kedua terjadi peperangan melawan Persia pada waktu pemimpin mereka merobek-robek al-Qur'an di depan utusan Nabi Saw dan memerintahkan beberapa tentara untuk pergi dan membawa "Si Muhammad hidup-hidup” kepadanya. Kedua reaksi ini dipahami sebagai deklarasi perang. Akan tetapi, pada mayoritas kasus lainnya, pesan Nabi disampaikan tanpa perangan atau ketegangan sedikit pun.

Hubungan politik antara Muslim dan non Muslim, setelah mengkaji tindakan Nabi Saw, secara fundamental, harus dipahami bahwa kaum Muslim berpegang pada prinsip perdamaian, bukan peperangan. Dalam konteks itu pula, Nabi Saw tidak memiliki kepentingan pribadi dalam menyampaikan pesan ke umat dan tidak mengambil alih kekuasaan. Realitas kesejarahan memperlihatkan bahwa Nabi Saw selalu memerangi para pemimpin disebabkan pembunuhan, pengkhianatan, atau ketidakadilan yang mereka lakukan, dan Nabi saw tidak pernah memerangi masyarakat hanya karena mereka menolak Islam. ${ }^{19}$

Tidak dapat dipungkiri bahwa term al-Harb (perang) konotasinya adalah pembunuhan. Secara konsepsional, dalam pandangan Islam perang itu tidak identik dengan pembunuhan. Suatu kesepakatan universal menunjukkan bahwa sekali suatu hidup terwujud maka ia harus dilindungi dan dihormati. Ajaran agama melarang pembunuhan, serta pandangan bahwa pembunuhan adalah kejahatan besar, tidak bisa lain daripada harus diinterpretasikan bahwa menurut agama, hidup itu secara intrinsik adalah berharga dan harus dilindungi. Demikian pula dalam bentuknya yang lebih positif, perintah agama untuk

${ }^{19}$ Tariq Ramadan, Teologi Dialog Islam-Barat Pergumulan Muslim Eropa, (Bandung: Penerbit Mizan, 2002), h. 141. 
membantu dan menolong sesama manusia, dan pandangan bahwa tindakan itu sebagai kebajikan besar.

Apa pun alasan dan latar belakangnya membunuh sesama manusia merupakan hal yang dikutuk oleh agama. Maka jika ada seorang "teroris" yang berpandangan bahwa "menjadi pengantin bom" merupakan jalan pintas menuju sorga, itu adalah ajaran yang sesat. Doktrin politik yang tidak berdasar. Karena dalam alQur'ān ditegaskan :

"Oleh karena itu Kami tetapkan (suatu hukum) bagi Bani Israil, bahwa: Barangsiapa yang membunuh seorang manusia, bukan karena orang itu (membunuh) orang lain[Yakni: membunuh orang bukan karena qishaash.], atau bukan karena membuat kerusakan dimuka bumi, maka seakan-akan dia telah membunuh manusia seluruhnya[Hukum ini bukanlah mengenai Bani Israil saja, tetapi juga mengenai manusia seluruhnya. Allah memandang bahwa membunuh seseorang itu adalah sebagai membunuh manusia seluruhnya, karena orang seorang itu adalah anggota masyarakat dan karena membunuh seseorang berarti juga membunuh keturunannya]. dan Barangsiapa yang memelihara kehidupan seorang manusia, Maka seolah-olah Dia telah memelihara kehidupan manusia semuanya. dan Sesungguhnya telah datang kepada mereka Rasul-rasul Kami dengan (membawa) keteranganketerangan yang jelas, kemudian banyak diantara mereka sesudah itu[Ialah: sesudah kedatangan Rasul membawa keterangan yang nyata.] sungguh-sungguh melampaui batas dalam berbuat kerusakan dimuka bumi." (Q.S. al-Maidah/5 : 32).

Perhatikan dengan cermat ayat di atas, betapa konsepsi Islam tentang kemanusiaan begitu agung dan mulia. Maka jika ajaran Islam diamalkan dengan benar, kehidupan di muka bumi akan damai dan tentram, karena Islam itu merupakan rahmat bagi sekalian alam. Cukup dengan ayat di atas dapat ditegaskan bahwa "terorisme" dalam arti tindakan kekerasan, perang dan pemboman dengan mengakibatkan tragedi kemanusiaa, seperti kasus di menara kembar Amerika Serikat, Bom Bali I dan II, bom JW Mariot I dan II dan bom Ritz Carlton, yang kesemuanya telah merenggut ratusan bahkan ribuan nyawa orang-orang yang tidak berdosa; ini jelas-jelas tidak benar kalau bersumber dari ajaran Islam.

Nilai-nilai ajaran Islam diberimakna universal, yaitu iman dan keadilan dan mempertanggungjawabkan tindakan sosial dan politiknya di hadapan Tuhan. Oleh karena itu, tidak relevan 
mendikhotomi, atas dasar kebencian, ini golongan kami dan ini golongan mereka. Ini orang Barat dan yang ini orang Timur karenanya harus diperangi, harus dibom disebabkan beda akidah, dan sebagainya. Hal ini ditegaskan dalam ayat berikut ini:

Ayat 9. menyebutkan: "dan kalau ada dua golongan dari mereka yang beriman itu berperang hendaklah kamu damaikan antara keduanya! tapi kalau yang satu melanggar Perjanjian terhadap yang lain, hendaklah yang melanggar Perjanjian itu kamu perangi sampai surut kembali pada perintah Allah. kalau Dia telah surut, damaikanlah antara keduanya menurut keadilan, dan hendaklah kamu Berlaku adil; Sesungguhnya Allah mencintai orang-orang yang Berlaku adil".

Ayat 10. menyebutkan: "orang-orang beriman itu Sesungguh-nya bersaudara. sebab itu damaikanlah (perbaikilah hubungan) antara kedua saudaramu itu dan takutlah terhadap Allah, supaya kamu mendapat rahmat."

Ayat 11. menyebutkan: "Hai orang-orang yang beriman, janganlah sekumpulan orang laki-laki merendahkan kumpulan yang lain, boleh Jadi yang ditertawakan itu lebih baik dari mereka. dan jangan pula sekumpulan perempuan merendahkan kumpulan lainnya, boleh Jadi yang direndahkan itu lebih baik. dan janganlah suka mencela dirimu sendiri[Jangan mencela dirimu sendiri Maksudnya ialah mencela antara sesama mukmin karana orang-orang mukmin seperti satu tubuh.] dan jangan memanggil dengan gelaran yang mengandung ejekan. seburuk-buruk panggilan adalah (panggilan) yang buruk sesudah iman[Panggilan yang buruk ialah gelar yang tidak disukai oleh orang yang digelari, seperti panggilan kepada orang yang sudah beriman, dengan panggilan seperti: Hai fasik, Hai kafir dan sebagainya.] dan Barangsiapa yang tidak bertobat, Maka mereka Itulah orang-orang yang zalim."

Ayat 12. menyebutkan:" Hai orang-orang yang beriman, jauhilah kebanyakan purba-sangka (kecurigaan), karena sebagian dari purbasangka itu dosa. dan janganlah mencari-cari keburukan orang dan janganlah menggunjingkan satu sama lain. Adakah seorang diantara kamu yang suka memakan daging saudaranya yang sudah mati? Maka tentulah kamu merasa jijik kepadanya. dan bertakwalah kepada Allah. Sesungguhnya Allah Maha Penerima taubat lagi Maha Penyayang."

Ayat 13. menyebutkan: "Hai manusia, Sesungguhnya Kami menciptakan kamu dari seorang laki-laki dan seorang perempuan dan menjadikan kamu berbangsa - bangsa dan bersuku-suku supaya 
kamu saling kenal-mengenal. Sesungguhnya orang yang paling mulia diantara kamu disisi Allah ialah orang yang paling taqwa diantara kamu. Sesungguhnya Allah Maha mengetahui lagi Maha Mengenal."( Q.S al-Hujurat/49; 9-13).

Ayat-ayat tersebut menegaskan bahwa yang paling penting bukanlah identitas etnis, suku, ras atau jenis kelamin, melainkan ketakwaan. Nilai takwa dapat diperoleh jika dapat mewujudkan sikap toleran, saling menghargai antar sesama manusia. Tidak dibenarkan saling mencemooh, apa lagi diiringi dengan sikap sombong dan membanggakan ras, suku atau golongan. Semua jenis apa pun dan kelebihan apa pun yang dianugerahkan Tuhan padanya, tetap memiliki nilai yang sama di hadapan Tuhan, dan oleh karenanya sesama manusia yang merupakan sama-sama makhluk Tuhan harus menjaga solidaritas kemanusiaan, dan tidak dibenarkan saling berperang dan saling men"teror" satu sama lainnya.

\section{F. Fenomena Geopolitik Baru}

Sebagai fenomena baru, globalisasi belum memiliki definisi yang mapan, sehingga tergantung dari sisi mana orang melihatnya. Ada yang memandangnya sebagai suatu proses sosial, atau proses sejarah, atau proses alamiah yang akan membawa seluruh bangsa dan negara di dunia makin terikat satu sama lain, mewujudkan satu tatanan kehidupan baru atau kesatuan koeksistensi dengan menying-kirkan batas-batas geografis, ekonomi dan budaya masyarakat. Metos yang berkembang adalah bahwa proses globalisasi akan membuat dunia seragam. Proses globalisasi akan menghapus identitas dan jati diri. Kebudayaan lokal atau etnis akan ditelan oleh kekuatan budaya besar atau kekuatan budaya global. Anggapan atau jalan pikiran ini tidak sepenuhnya benar. Kemajuan teknologi komunikasi memang telah membuat batasbatas dan jarak menjadi hilang tak berguna. Namun demikian justru berpendapat sebaliknya, yaitu semakin kita menjadi universal, tindakan kita semakin kesukuan, dan berpikir lokal, bertindak global. Maksudnya tentu saja agar kita mengkonsentrasikan kepada hal-hal yang bersifat etnis, yang hanya dimiliki oleh kelompok 
tertentu atau masyarakat itu sendiri sebagai modal pengembangan ke dunia Internasional ${ }^{20}$

Pandangan Naisbitt ini jika kita kaitkan dengan peradaban Islam awal yang unik, memiliki kekuatan spiritual, dapat berkembang menuju Adikuasa Dunia, setelah menaklukkan Persia dan Romawi. Di sini globalisasi menjadi bagian dari geografi politik karena di dalamnya terdapat proses pergeseran peta politik dunia. Pada abad 21 ini, Amerika Serikat merasa "terancam" oleh adanya pergeseran pengaruh peta politik dunia dan berusaha memperkuat dirinya dengan cara memperbaiki citra dirinya lalu mendiskriditkan negara lain.

Amerika Serikat terlihat di forum dunia, seolah-olah menjadi pahlawan demokrasi, tetapi pada sisi lain tidak segan-segan menuduh sebagian negara yang tidak sependapat disebut negara anti demokrasi dan atau menyebutnya sebagai "poros setan”. Selain itu, sang Super Power juga mencoba mematahkan munculnya tokohtokoh dunia yang berpotensi dengan cara merusak nama baiknya dengan sebutan "teroris". Isu penumpasan terorisme memuncak sejak peristiwa 11 September 2001 dengan melakukan gerakan agresi militer ke Afganistan. Dengan cara tersebut ia mendapatkan dua keuntungan; simpati dari warga dunia sebagai "penumpas" teroris dan dapat "mengangkangi” negara yang diagresinya sebagai penyedia sumber daya cadangan bagi kepentingan nasionalnya. Agresi militer yang dilakukan oleh Amerika Serikat itu merupakan teror keras ${ }^{21}$ terhadap negara-negara kecil terutama negara-negara Muslim, karena sangat berlawanan dengan kaedah-kaedah perang yang harus ditegakkan. Pembombardiran daerah sipil, daerah pemukiman penduduk dan meluluhlantakkan fasilitas umum.

Islam tidak mengenal istilah perang suci (holy war). Perang dilakukan jika terjadi serangan dari luar yang membahayakan

\footnotetext{
${ }^{20}$ John Naisbitt, Global Paradox, 1988.

${ }^{21}$ Doktrin perang mencakup tiga kategori; pertama, harus memenuhi kriteria untuk memperbaiki suatu kejahatan publik atau sebagai upaya pembelaan diri; kedua, harus dilakukan pada pelaku yang salah, dan bukan kepada warga sipil yang terjebak dalam suatu keadaan yang tidak mereka ciptakan. Pengeboman terhadap daerah hunian warga sipil sangat tidak dibenarkan dan ketiga, mengatur tentang proses mengakhiri perang. Lihat, Sri Hayati dan Ahmad Yani, Geografi Politik, (Bandung : Refika Aditama, 2007), h. 123-124.
} 
eksistensi umat Islam. Perang tidak dibenarkan menyerang orang-orang yang telah tunduk kepada aturan Allah dan atau mereka yang telah mengadakan perjanjian damai. ${ }^{22}$ Perang yang mengatasnamakan penegakan Islam tetapi tidak mengikuti caracara Nabi Saw tidak bisa disebut jihad, apa lagi dengan kekerasan. Larangan dalam peperangan harus diindahkan, dengan dasar etika itu, Islam tidak membenarkan terorisme. Karena terorisme buka sebuah cara dalam etika perang.

Perang yang dilancarkan Amerika terhadap terorisme, meiliki motivasi tertentu. Bukti otentik adanya faktor kepentingan bahwa yang menyertai tindakan Barat dalam aksi-aksi politik dan militer yang menyebabkan timbulnya calsh antara Barat dan beberapa negara Islam adalah fenomena Perang Teluk jilid II di Irak. Dengan dalih memerangi terorisme dan atau menumbangkan kekuasaan Saddam Husein, bertujuan menguasai sumber-sumber minyak yang konon kandungannya nyaris sepadan dengan yang dipunyai oleh Arab saudi. Lebih dari itu, dengan runtuhnya pemerintahan Saddam Husein di Irak, akan lebih mengukuhkan hegemoni Amerika Serikat sebagai satu-satunya adidaya di muka bumi ini berhak berbuat apa saja untuk melaksanakan kepentingan globalnya.

Bercermin dari gambaran di atas, nampaknya Indonesia harus ekstra hati-hati terhadap fenomena geopolitik baru, yaitu perang antara ideologi demokrasi melawan terorisme. Di sini terlihat bayang-bayang skenario global. Indonesia "diobok-obok", atas nama menumpas teroris, tetapi pemerintah telak melakukan teror terhadap rakyatnya sendiri. Pesantren sebagai pusat pradaban Islam yang mewariskan tradisi keilmuan, secara "membabi buta" dipahami oleh pemerintah sebagai sarang teroris. Ada stu dua ekor tikus maling padi, tetapi lumbungnya dibakar. Ironi sekali,

${ }^{22}$ Aturan perang dalam Islam lebih rinci lagi, yaitu : jangan berkhianat; jangan berlebih-lebihan; jangan inkar janji; jangan mencincang mayat; jangan membunuh anak kecil, orang tua renta dan wanita; jangan membakar pohon, menebang atau menyembelih binatang ternak kecuali untuk dimakan; jangan mengusik orang-orang yang taat kepada agama yang dianutnya (ahli kitab) yang sedang beribadah. Jika melakukan larangan dalam berperang maka mereka dianggap berdosa dan menyalahi misi perang secara Islam. 
dan sangat memilukan dan sekaligus memalukan dan merusak pencitraan Indonesia itu sendiri di pentas Internasional.

Kasus KKN semakin menjadi-jadi, perekonomian semakin terpuruk, huru hara politik, mulai dari prose pemilu sampai ke pelantikan Presiden, ditambahkeruhkan oleh persoalan terorisme. Biaya pendidikan yang melambung tinggi. Ekonomi, baik makro maupun mikro dikendalikan asing. Ambruknya berbagai imfrastruktur, mulai dari transfortasi, kreta, bus, pesawat, kapal laut terjadi kecelakaan demi kecelakaan, kemudian munculnya bencana alam yang tidak berkesudahan. Alih-alih menguatnya NKRI malah memunculkan pergolakan-pergolakan baru di sana sini. Hati-hati hegemoni Amerika mengintai.

\section{G. Penutup}

Konsep dua entitas dār al-Islām dan dār al- harb dalam dunia kontemporer tidak mungkin dapat dipadukan, karena keduanya tidak memiliki eksistensi yang jelas dan pasti, dan perjanjianperjanjian, disebabkan pengaruh politik yang ruwet dan perebutan kekuasaan yang tidak seimbang, tidak bisa dianggap sebagai tanda persetujuan antara dua atau lebih pemerintahan yang bebas dan independen. Terkait dengan kehidupan demokrasi yang terbuka, agaknya rumah Indonesia menjadi tawaran solusi dari benturan kedua entitas tersebut. Rumah Indonesia yang damai, yang aman, yang memberikan jaminan dengan konsep pluralisme demokratisnya. Islam Indonesia adalah Islam yang unik dan moderat, membawa kesejukan dan kedamaian, yang secara substantif adalah dār al-Islām yang hakiki.

Definisi geografis tentang dār al- Islām dan pembagianpembagian internnya tidak penting lagi karena dalam Islam, hukum itu bersifat personal dan tidak teritorial. Bagian-bagian lain dari dār al-Islām kategori yang paling penting dari segi geografi, terbuka bagi Ahli Kitab (Masehi dan Yahudi) yang bisa tinggal di situ sebagai orang "yang dilindungi" atau biasa bepergian ke situ sebagai orang asing yang membawa tanda masuk. Dār al-harb tidak meliputi seluruh negara yang bukan Islam yang sesungguhnya dapat juga menikmati eksistensi legitime dan kemerdekaan yang sempurna secara de facto atau de jure atau dengan sayarat-syarat tertentu. Ciriciri dār al- harb tidak adanya lembaga-lembaga yang menegakkan 
perdamaian dan keadilan, dan tidak diperlakukannya hukum dan jiwa al-Qur'ān. itu adalah kawasan kekerasan, kebodohan dan kezhaliman (tirani). [.]

\section{Daftar Pustaka}

Abdurrahman, Hafidz, Diskursus Islam Politik Spiritual, Bogor: Al Azhar Press, 2004.254.

Adams, Ian, Ideologi Politik Mutakhir Konsep, Ragam, Kritik, dan Masa Depannya, Yogyakarta: Penerbit Qalam, 2004.

al-Qaththān, Syaikh Mannā', Iqāmah al-Muslìm fì Balad Ghair Islāmī (Perkampungan Muslim di Negara Non-Muslim), Paris: 1993.

Black, Anthoni, Pemikiran Politik Islam Dari Masa Nabi Hingga Masa Kini, Jakarta: Serambi, 2006.

Boisard, Marcel A., Humanisme dalam Islam, (terjemahan M. Rasjidi), Jakarta: Bulan Bintang, 1980.

Departemen Pendidikan dan Kebudayaan, Kamus Besar bahasa Indonesia edisi kedua, Jakarta: Balai Pustaka, 1995.

Ghunaimi, Mohammad T., The Muslim Conception of International Law and the Western Approach, La Haye : Nijhoff, 1968.

Hayati, Sri dan Ahmad Yani, Geografi Politik, Bandung: Refika Aditama, 2007.

Hodgson, Marshall G. S., The Venture of Islam (Iman dan Sejarah dalam Peradaban Dunia Masa KlasikIslam)Buku Kedua, terjemahan Mulyadhi Kartanegara, Jakarta: Paramadina, 2002.

Jaiz, Hartono Ahmad, Aliran dan Paham Sesat di Indonesia, Jakarta: Pustaka Al-Kautsar, 2007.

Lawrence, Bruce B., Islam Tidak Tunggal Melepaskan Islam dari Kekerasan, Jakarta: Serambi, 2004.

Madjid, Nurcholish, Islam Doktrin dan Peradaban Sebuah Telaah Kritis tentang Masalah Keimanan, Kemanusiaan, dan Kemodernan, Jakarta: Paramadina, 2000. 
Moussalli, Ahmad, Radical Islamic Fundamentalism: The Ideological and Political Discourse of Sayyid Quthb, Beirut: American University of Beirut, 1992.

Naisbitt, John, Global Paradox, 1988

Quthb, Sayyid, “Ma'alim fi al-Thariq, Cairo: Dar ash-Shuruq, 1964.

Quthb, Sayyid, Milestones, Cedar Rapids, Iwoa: Unity Publishing, t.th.

Ramadan, Tariq, Teologi Dialog Islam-Barat Pergumulan Muslim Eropa, Bandung: Penerbit Mizan, 2002.

Schuon, Frithjof, Islam dan Filsafat Perenial, Bandung : Mizan, 1993. 